\title{
PENERAPAN NILAI NILAI PANCASILA DALAM KEHIDUPAN SEHARI HARI DAN SEBAGAI PENDIDIKAN KARAKTER
}

\author{
Yohana.R.U.Sianturi \& Dinie Anggraeni Dewi \\ Universitas Pendidikan Indonesia \\ yohana@upi.edu
}

\begin{abstract}
Abstrak
Penelitian ini bertujuan mengetahui implementasi nilai-nilai Pancasila sebagai asas materi muatan pembentukan peraturan perundang-undangan dalam Pasal 6 UU No. 12/2011. Penelitian ini merupakan jenis penelitian normatif bersifat preskriftif dengan menggunakan pendekatan undang-undang, historis, dan konseptual. Jenis dan sumber bahan hukum yang digunakan yaitu, primer dan sekunder. Teknik pengumpulan data menggunakan literature research. Analisa bahan hukum menggunakan silogisme deduksi. Berdasarkan hasil penelitian dan pembahasan dihasilkan kesimpulan, asas materi muatan telah memuat nilai-nilai Pancasila, tetapi belum semua nilai-nilai Pancasila termuat dalam asas materi muatan. Nilai-nilai dari sila Ketuhanan Yang Maha Esa belum termuat dalam asas materi muatan pembentukan peraturan perundang-undangan.
\end{abstract}

Kata Kunci: Pancasila, Norma Dasar, Sumber Hukum, Peraturan Perundang-undangan

\begin{abstract}
This study aims to determine the implementation of Pancasila values as a material principle for the formation of statutory regulations in Article 6 of Law no. 12/2011. This research is a type of normative research is prescriptive in nature by using a statutory, historical, and conceptual approach. Types and sources of legal materials used, namely, primary and secondary. Data collection techniques using literature research. Analysis of legal materials using a deductive syllogism. Based on the results of the research and discussion, it was concluded that the principle of content material contained the values of Pancasila, but not all of the values of Pancasila were contained in the principle of content material. The values of the precepts of the One and Only Godhead have not been included in the material principle of the content of the formation of legislation.
\end{abstract}

Keywords: Pancasila, Basic Norms, Legal Sources, Legislation

\section{PENDAHULUAN}

Pancasila dianggap sebagai sesuatu yang sakral yang setiap warganya harus hafal dan mematuhi segala isi dalam pancasila tersebut. Namun sebagian besar warga negara Indonesia hanya menganggap pancasila sebagai dasar negara/ideologi semata tanpa memperdulikan makna dan manfaatnya dalam kehidupan. Tanpa manusia sadari nilai-nilai makna yang terkandung dalam pancasila sangat berguna dan bermanfaat (Nurgiansah, 2020).

Banyaknya terjadi penyimpangan /kesalahan tertentu sebenarnya berakar dari tidak mengamalkannya nilai-nilai yang terkandung dalam pancasila itu sendiri. Maka dari itu pentingnya memahami pancasila tidak hanya mengerti namun juga mengamalkan dan melaksanakan nilai-nilai yang terkandung dalam pancasila sebagai pendidikan karakter. Pendidikan karakter yang merupakan upaya mewujudkan amanat pacasila dan Pembukaan UUD 1945 dilatar belakangi oleh realita yang berkembang saat ini di lembaga pendidikan (Dewantara, Hermawan, et al., 2021).

Dengan prilaku-prilaku yang tidak sesuai dengan karakter bangsa Indonesia saat ini. Membina dan mendidik karakter, dalam arti untuk membentuk "positive character" generasi muda bangsa ini. Agar positive character terbentuk, maka perlu pembiasaan "mandiri, sopan santun, kreatif dan tangkas, rajin bekerja, dan punya tanggung jawab" (Nurgiansah, 2021a). 
Pendidikan pancasila dalam kehidupan sehari hari dapat membrikan dampak yang baik untuk masyarakat agar masyarakat mematuhi dan menganut nilai nilai dalam pancasila karena nilai yang terkandung dalam pancasila mempunyai banyak makna untuk kehidupan sehari hari dalam beragama, memberikan pendapat dan lain-lain (Dewantara \& Nurgiansah, 2021a)

\section{METODE PENELITIAN}

Penelitian ini merupakan jenis penelitian normatif bersifat preskriftif dengan menggunakan pendekatan undangundang, historis, dan konseptual. Jenis dan sumber bahan hukum yang digunakan yaitu, primer dan sekunder. Teknik pengumpulan data menggunakan literature research (Dewantara \& Nurgiansah, 2021b).

\section{HASIL PENELITIAN DAN PEMBAHASAN Hasil Penelitian}

Di dalam mewujudkan pancasila sebagai falsafah bangsa sebagai cita-cita kehidupan, maka terbentuknya Negara Kesatuan Republik Indonesia yang kokoh kuat menjadi syarat. Untuk membangun NKRI ini kita harus ingat bahwa persatuan dan kesatuan bangsa itu tidak akan terjadi dengan sendirinya (spontan), akan tetapi harus diusahakan dengan kesadaran kita (Dewantara, Nurgiansah, et al., 2021).

Untuk itu diperlukan pendidikan karakter untuk menumbuhkan kesadaran mengenai rasa kesatuan dan persatuan berbangsa, juga memperbaiki nilai-nilai yang telah menyimpang dan mengembalikannya ke nilai-nilai yang sesuai demi kesatuan Negara Indonesia. Dan mengamalkan nilai-nilai pancasila dalam kehidupan melalui pendidikan karakter bagi para generasi bangsa (Nurgiansah, 2021c).

\section{Pembahasan}

Nilai adalah ukuran, patokan-patokan, anggapan-anggapan keyakinankeyakinan yang ada di dalam masyarakat. Nilai digunakan sebagai patokan seseorang berperilaku dalam masyarakat. Selain itu, nilai memberi arah bagi tindakan seseorang. Nilai dianut oleh banyak orang dalam suatu masyarakat mengenai sesuatu yang benar, pantas, luhur, dan baik untuk dilakukan (Nurgiansah, 2021d).

Menurut (Nurgiansah, 2021b), fungsi nilai diantaranya, nilai sebagai pembentuk cara berfikir dan berprilaku yang ideal dalam masyarakat. Nilai dapat menciptakan semangat pada manusia untuk mencapai sesuatu yang diinginkannya. Nilai dapat digunakan sebagai alat pengawas prilaku seseorang dalam masyarakat. Nilai dapat mendorong, menuntun, dan menekan orang untuk berbuat baik. Nilai dapat berfungsi sebagai alat solideritas di antara anggota masyarakat

\section{Makna Dan Nilai-Nilai Yang Terkandung dalam Pancasila}

Pancasila yang merupakan dasar Negara Republik Indonesia memiliki makna dan nilai-nilai luhur dalam setiap silasilanya, karena setiap butir pancasila itu dirumuskan dari nilai-nilai yang sudah ada sejak zaman dulu dalam kehidupan pribadi bangsa Indonesia. Adapun makna dan nilainilai yang terkandung dalam setiap sila-sila itu adalah sebagai berikut:

\section{Ketuhanan (Religiusitas)}

Nilai religius adalah nilai yang berkaitan dengan keterkaitan individu dengan sesuatu yang dianggapnya memiliki kekuatan sakral, suci, agung dan mulia. Memahami Ketuhanan sebagai pandangan hidup adalah mewujudkan masyarakat yang berketuhanan, yakni membangun masyarakat Indonesia yang memiliki jiwa maupun semangat untuk mencapai ridho Tuhan dalam setiap perbuatan baik yang dilakukannya. Dari sudut pandang etis 
keagamaan, negara berdasar Ketuhanan Yang Maha Esa itu adalah negara yang menjamin kemerdekaan tiap-tiap penduduknya untuk memeluk agama dan beribadat menurut agama dan kepercayaan masing-masing. Dari dasar ini pula, bahwa suatu keharusan bagi masyarakat warga Indonesia menjadi masyarakat yang beriman kepada Tuhan, dan masyarakat yang beragama, apapun agama dan keyakinan mereka.

\section{Kemanusiaan (Moralitas)}

Kemanusiaan yang adil dan beradab, adalah pembentukan suatu kesadaran tentang keteraturan, sebagai asas kehidupan, sebab setiap manusia mempunyai potensi untuk menjadi manusia sempurna, yaitu manusia yang beradab. Manusia yang maju peradabannya tentu lebih mudah menerima kebenaran dengan tulus, lebih mungkin untuk mengikuti tata cara dan pola kehidupan masyarakat yang teratur, dan mengenal hukum universal. Kesadaran inilah yang menjadi semangat membangun kehidupan masyarakat dan alam semesta untuk mencapai kebahagiaan dengan usaha gigih, serta dapat diimplementasikan dalam bentuk sikap hidup yang harmoni penuh toleransi dan damai (Nurgiansah \& Al Muchtar, 2018).

\section{Persatuan Indonesia (Kebangsaan)}

Persatuan adalah gabungan yang terdiri atas beberapa bagian, kehadiran Indonesia dan bangsanya di muka bumi ini bukan untuk bersengketa. Bangsa Indonesia hadir untuk mewujudkan kasih sayang kepada segenap suku bangsa dari Sabang sampai Merauke. Persatuan Indonesia, bukan sebuah sikap maupun pandangan dogmatik dan sempit, namun harus menjadi upaya untuk melihat diri sendiri secara lebih objektif dari dunia luar. Negara Kesatuan Republik Indonesia terbentuk dalam proses sejarah perjuangan panjang dan terdiri dari bermacam-macam kelompok suku bangsa, namun perbedaan tersebut tidak untuk dipertentangkan tetapi justru dijadikan persatuan Indonesia (Nurgiansah et al., 2020).

\section{Permusyawaratan dan Perwakilan}

Sebagai makhluk sosial, manusia membutuhkan hidup berdampingan dengan orang lain, dalam interaksi itu biasanya terjadi kesepakatan, dan saling menghargai satu sama lain atas dasar tujuan dan kepentingan bersama. Prinsip-prinsip kerakyatan yang menjadi cita-cita utama untuk membangkitkan bangsa Indonesia, mengerahkan potensi mereka dalam dunia modern, yakni kerakyatan yang mampu mengendalikan diri, tabah menguasai diri, walau berada dalam kancah pergolakan hebat untuk menciptakan perubahan dan pembaharuan. Hikmah kebijaksanaan adalah kondisi sosial yang menampilkan rakyat berpikir dalam tahap yang lebih tinggi sebagai bangsa, dan membebaskan diri dari belenggu pemikiran berasaskan kelompok dan aliran tertentu yang sempit (Alfaqi, 2016).

\section{Keadilan Sosial}

Nilai keadilan adalah nilai yang menjunjung norma berdasarkan ketidak berpihak kan, keseimbangan, serta pemerataan terhadap suatu hal. Mewujudkan keadilan sosial bagi seluruh rakyat Indonesia merupakan cita-cita bernegara dan berbangsa. Itu semua bermakna mewujudkan keadaan masyarakat yang bersatu secara organik, dimana setiap anggotanya mempunyai kesempatan yang sama untuk tumbuh dan berkembang serta belajar hidup pada kemampuan aslinya. Segala usaha diarahkan kepada potensi rakyat, memupuk perwatakan dan peningkatan kualitas rakyat, sehingga kesejahteraan tercapai secara merata (Bahrudin, 2019).

Dari uraian nilai-nilai kelima butir Pancasila itu kita dapat melihat betapa apik 
dan luhur nilai-nilai yang terkandung didalamnya. Sehingga sangat disayangkan apabila nilai-nilai itu hanya menjadi wacana belaka dan tidak terealisasikan sebagaimana mestinya dalam kehidupan seharihari karena kurangnya kesadaran dan sikap menjiwai Pancasila yang kurang. Nilai-nilai tersebut mungkin bisa lebih merasuk ke dalam hati dan jiwa setiap rakyat Indonesia apabila nilai-nilai itu telah tertanam dalam setiap individu dalam hidup di tengah keluarga, bersekolah, dan berada ditengahtengah masyarakat (Cahyo Pamungkas, 2015).

\section{Penerapan Nilai-Nilai Pancasila dalam Kehidupan Sehari-Hari}

Nilai-nilai yang terkandung dalam Pancasila dari Sila ke I sampai Sila Sila ke V yang harus diaplikasikan atau dijabarkan dalam setiap kegiatan pengelolaan lingkungan hidup adalah sebagai berikut: Dalam Sila Ketuhanan Yang Maha Esa terkandung nilai religius, antara lain: Kepercayaan terhadap adanya Tuhan Yang Maha Esa sebagai pencipta segala sesuatu dengan sifat-sifat yang sempurna dan suci seperti Maha Kuasa, Maha Pengasih, Maha Adil, Maha Bijaksana dan sebagainya; Contohnya: Menyayangi tumbuh-tumbuhan dan merawatnya; selalu menjaga kebersihan dan sebagainya (Dedees, 2016).

Dalam Islam bahkan ditekankan, bahwa Allah tidak suka pada orang-orang yang membuat kerusakan di muka bumi, tetapi Allah senang terhadap orang-orang yang selalu bertakwa dan selalu berbuat baik. Lingkungan hidup Indonesia yang dianugerahkan Tuhan Yang Maha Esa kepada rakyat dan bangsa Indonesia merupakan karunia dan rahmat-Nya yang wajib dilestarikan dan dikembangkan kemampuannya agar tetap dapat menjadi sumber dan penunjang hidup bagi rakyat dan bangsa Indonesia serta makhluk hidup lainya demi kelangsungan dan peningkatan kualitas Hidup itu sendiri (Murdiono et al., 2020).

Sila Kemanusiaan Yang Adil Dan Beradab terkandung nilai-nilai perikemanusiaan yang harus diperhatikan dalam kehidupan sehari-hari. Dalam hal ini antara lain sebagai berikut: Pengakuan adanya harkat dan martabat manusia dengan segala hak dan kewajiban asasinya. Penerapan, pengamalan/ aplikasi sila ini dalam kehidupan sehari hari yaitu: Dapat diwujudkan dalam bentuk kepedulian akan hak setiap orang untuk memperoleh lingkungan hidup yang baik dan sehat; hak setiap orang untuk mendapatkan informasi lingkungan hidup yang berkaitan dengan peran dalam pengelolaan lingkungan hidup; hak setiap orang untuk berperan dalam rangka pengelolaan lingkungan hidup yang sesuai dengan ketentuan-ketentuan hukum yang berlaku dan sebagainya.

Dalam hal ini banyak yang bisa dilakukan oleh masyarakat untuk mengamalkan Sila ini, misalnya mengadakan pengendalian tingkat polusi udara agar udara yang dihirup bisa tetap nyaman; menjaga kelestarian tumbuhtumbuhan yang ada dilingkungan sekitar; mengadakan gerakan penghijauan dan sebagainya. Nilai-nilai Sila Kemanusiaan Yang Adil Dan Beradab ini ternyata mendapat penjabaran dalam UndangUndang No. 23 Tahun 1997 di atas, antara lain dalam Pasal 5 ayat (1) sampai ayat (3); Pasal 6 ayat (1) sampai ayat (2) dan Pasal 7 ayat (1) sampai ayat (2).

Dalam Pasal 5 ayat (1) dinyatakan, bahwa setiap orang mempunyai hak yang sama atas lingkungan hidup yang baik dan sehat; dalam ayat (2) dikatakan, bahwa setiap orang mempunyai hak atas informasi lingkungan hidup yang berkaitan dengan peran dalam pengelolaan lingkungan hidup; dalam ayat (3) dinyatakan, bahwa setiap orang mempunyai hak untuk berperan dalam rangka pengelolaan lingkungan hidup sesuai dengan peraturan perundang- 
undangan yang berlaku (Retnasari \& Hidayah, 2019).

Dalam Pasal 6 ayat (1) dikatakan, bahwa setiap orang berkewajiban memelihara kelestarian fungsi lingkungan hidup serta mencegah dan menanggulangi pencemaran dan perusakan lingkungan hidup dan dalam ayat (2) ditegaskan, bahwa setiap orang yang melakukan usaha dan/ atau kegiatan berkewajiban memberikan informasi yang benar dan akurat mengenai pengelolaan lingkungan hidup. Dalam Pasal 7 ayat (1) ditegaskan, bahwa masyarakat mempunyai kesempatan yang sama dan seluas-luasnya untuk berperan dalam pengelolaan lingkungan hidup; dalam ayat (2) ditegaskan, bahwa ketentuan pada ayat (1) di atas dilakukan dengan cara: Meningkatkan kemandirian, keberdayaan masyarakat dan kemitraan; Menumbuh kembangkan kemampuan dan kepeloporan masyarakat; Menumbuhkan ketanggap segeraan masyarakat untuk melakukan pengawasan sosial; Memberikan saran pendapat; Menyampaikan informasi dan /atau menyampaikan laporan.

Dalam Sila Persatuan Indonesia terkandung nilai persatuan bangsa, dalam arti dalam hal-hal yang menyangkut persatuan bangsa patut diperhatikan aspekaspek sebagai berikut: Persatuan Indonesia adalah persatuan bangsa yang mendiami wilayah Indonesia serta wajib membela dan menjunjung tinggi (patriotisme); Pengakuan terhadap Ke Bhinneka Tunggal Ika dan suku bangsa (etnis) dan kebudayaan bangsa (berbeda-beda namun satu jiwa) yang memberikan arah dalam pembinaan kesatuan bangsa; Cinta dan bangga akan bangsa dan Negara Indonesia (nasionalisme) (Sutiyono, 2018).

Penerapan sila ini dalam kehidupan sehari-hari, antara lain: Dengan melakukan inventarisasi tata nilai tradisional yang harus selalu diperhitungkan dalam pengambilan kebijaksanaan dan pengendalian pembangunan lingkungan di daerah dan mengembangkannya melalui pendidikan dan latihan serta penerangan dan penyuluhan dalam pengenalan tata nilai tradisional dan tata nilai agama yang mendorong perilaku manusia untuk melindungi sumber daya dan lingkungan (Wahyudi, 2017)

Di beberapa daerah tidak sedikit yang mempunyai ajaran turun temurun mewarisi nilai-nilai leluhur agar tidak melakukan perbuatan-perbuatan yang dilarang oleh ketentuan-ketentuan adat di daerah yang bersangkutan, misalnya ada larangan untuk menebang pohonpohon tertentu tanpa ijin sesepuh adat; ada juga yang dilarang memakan binatang-bintang tertentu yang sangat dihormati pada kehidupan masyarakat yang bersangkutan dan sebagainya. Secara tidak langsung sebenarnya ajaran ajaran nenek leluhur ini ikut secara aktif melindungi kelestarian alam dan kelestarian lingkungan di daerah itu. Bukankah hal ini sudah mengamalkan Pancasila dalam kehidupan masyarakat yang bersangkutan sehari-hari.

Dalam Sila Kerakyatan Yang Dipimpin

Oleh Hikmat Kebijaksanaan Dalam Permusyawaratan Perwakilan terkandung nilai-nilai kerakyatan. Dalam hal ini ada beberapa hal yang harus dicermati, yakni: Mewujudkan, menumbuhkan, mengembangkan dan meningkatkan kesadaran dan tanggung jawab para pengambil keputusan dalam pengelolaan lingkungan hidup; Mewujudkan, menumbuhkan, mengembangkan dan meningkatkan kesadaran akan hak dan tanggung jawab masyarakat dalam pengelolaan lingkungan hidup; Mewujudkan, menumbuhkan, mengembangkan dan meningkatkan kemitraan, Masyarakat, dunia usaha dan pemerintah dalam upaya pelestarian daya dukung dan daya tampung lingkungan hidup.

Dalam Sila Keadilan Sosial Bagi Seluruh Rakyat Indonesia terkandung nilai keadilan sosial. Dalam hal ini harus diperhatikan beberapa aspek berikut, 
antara lain: Penerapan sila ini tampak dalam ketentuan-ketentuan hukum yang mengatur masalah lingkungan hidup. Sebagai contoh, dalam Ketetapan MPR RI Nomor IV/MPR/1999 tentang Garis-Garis Besar Haluan Negara (GBHN), Bagian H yang mengatur aspek-aspek pengelolaan lingkungan hidup dan pemanfaatan sumber daya alam (Yunita \& Suryadi, 2018).

Dalam ketetapan MPR ini hal itu diatur sebagai berikut (Penabur Ilmu, 1999 : 40): Mengelola sumber daya alam dan memelihara daya dukungnya agar bermanfaat bagi peningkatan kesejahteraan rakyat dari generasi ke generasi. Meningkatkan pemanfaatan sumber daya alam dan lingkungan hidup dengan melakukan konservasi, rehabilitasi dan penghematan penggunaan dengan menerapkan teknologi ramah lingkungan. Mendelegasikan secara bertahap wewenang pemerintah pusat kepada pemerintah daerah dalam pelaksanaan pengelolaan sumber daya alam secara selektif dan pemeliharaan lingkungan hidup, sehingga kualitas ekosistem tetap terjaga yang diatur dengan undang-undang. Mendayagunakan sumber daya alam untuk sebesar-besarnya kemakmuran rakyat dengan memperhatikan kelestarian fungsi dan keseimbangan lingkungan hidup, pembangunan yang berkelanjutan, kepentingan ekonomi dan budaya masyarakat lokal serta penataan ruang yang pengaturannya diatur dengan undangundang

\section{Penerapan Nilai-Nilai Pancasila dalam Pendidikan Karakter}

Kebanyakan orang menyepelekan makna yang terkandung dalam pancasila itu sendiri. Penyimpangan-penyimpangan yang terjadi sebenarnya merupakan berawal dari tidak menerapkan nilai-nilai yang terkandung dalam pancasila pada karakter.
Oleh karena itu, memaknai kandungan nilai-nilai dalam pancasila seperti nilai ketuhanan, kemanusiaan, persatuan, kemasyarakatan serta sebuah keadilan merupakan suatu hal yang perlu diterapkan melalui pendidikan karakter agar bangsa Indonesia menjadi manusia yang taat beragama, perikemanusiaan, adil dan berguna bagi dirinya, orang lain, bangsa dan negara.

Pendidikan budaya dan karakter bangsa bertujuan mempersiapkan siswa menjadi warga negara yang lebih baik, yaitu warga negara yang memiliki kemampuan, kemauan, dan menerapkan nilai nilai Pancasila dalam kehidupannya sebagai warga negara (Puskur, 2010 : 8). Nilai Pendidikan Karakter terdiri dari: Religius: Sikap dan perilaku yang patuh dalam melaksanakan ajaran agama yang dianutnya, toleran terhadap pelaksanaan ibadah agama lain, dan hidup rukun dengan pemeluk agama lain. Jujur: Perilaku yang didasarkan pada upaya menjadikan diri sebagai orang yang selalu dapat dipercaya dalam perkataan, tindakan, dan pekerjaan.

Toleransi: Sikap dan tindakan yang menghargai perbedaan agama, suku, etnis, pendapat, sikap, dan tindakan orang lain yang berbeda dari diri. Disiplin: Tindakan yang menunjukkan perilaku tertib dan patuh pada berbagai ketentuan dan peraturan. Kerja keras: Perilaku yang menunjukkan upaya sungguh-sungguh dalam mengatasi berbagai hambatan belajar dan tugas, serta menyelesaikan tugas dengan sebaik-baiknya. Kreatif: Berpikir dan melakukan sesuatu untuk menghasilkan cara atau hasil baru dari sesuatu yang telah dimiliki.

Mandiri : Sikap dan perilaku yang tidak mudah tergantung pada orang lain dalam menyelesaikan tugas-tugas sendiri. Demokratis: Cara berpikir, bersikap, dan bertindak yang menilai sama hak dan kewajiban dirinya dan orang lain. Rasa ingin tahu: Sikap dan tindakan yang selalu 
berupaya untuk mengetahui lebih mendalam dan meluas dari sesuatu yang dipelajarinya, dilihat, dan didengar. Cinta tanah air: Cara berpikir, bersikap, dan berbuat yang menunjukkan kesetiaan, kepedulian, dan penghargaan yang tinggi terhadap bahasa, lingkungan fisik, sosial, budaya, ekonomi, dan politik bangsa.

Bersahabat: Tindakan yang memperlihatkan rasa senang berbicara, bergaul, dan bekerja sama dengan orang lain. Cinta damai: Sikap, perkataan, dan tindakan yang menyebabkan orang lain merasa senang dan aman atas kehadiran diri. Peduli sosial: Sikap dan tindakan yang selalu ingin memberi bantuan pada orang lain dan masyarakat yang membutuhkan.

Semangat kebangsaan: Cara berpikir, bertindak, dan berwawasan yang menempatkan kepentingan bangsa dan negara di atas kepentingan diri dan kelompoknya. Menghargai prestasi: Sikap dan tindakan yang mendorong dirinya untuk menghasilkan sesuatu yang berguna bagi masyarakat, dan mengakui, serta menghormati keberhasilan orang lain. Peduli lingkungan: Sikap dan tindakan yang selalu berupaya mencegah kerusakan pada lingkungan alam di sekitarnya, dan mengembangkan upaya upaya untuk memperbaiki kerusakan alam yang sudah terjadi. Tanggung jawab: Sikap dan perilaku seseorang untuk melaksanakan tugas dan kewajibannya, yang seharusnya dia lakukan terhadap diri sendiri, masyarakat, lingkungan (alam, sosial dan budaya), negara dan Tuhan Yang Maha Esa.

Penerapan atau penanaman nilainilai setiap butiran pancasila yang harus diajarkan agar individu memiliki sikap dan perilaku yang sesuai dengan karakter luhur bangsa dan tidak menyimpang dari nilai pancasila yang sesuai dengan sila-sila dalam pancasila adalah sebagai berikut :

\section{Ketuhanan Yang Maha Esa}

Selalu tertib dalam menjalankan ibadah. Tidak berbohong kepada guru maupun teman. Bersyukur kepada Tuhan karena memiliki keluarga yang menyayanginya. Tidak meniru jawaban teman (menyontek) ketika ulangan ataupun mengerjakan tugas di kelas. Tidak mengganggu teman yang berlainan agama dalam beribadah. Menceritakan suatu kejadian berdasarkan sesuatu yang diketahuinya, tidak ditambah-tambah ataupun dikurangi. Tidak meniru pekerjaan temannya dalam mengerjakan tugas di rumah. Percaya pada kemampuan sendiri dalam melakukan apapun, karena Allah sudah memberian kelebihan dan kekurangan kepada setiap manusia.

\section{Kemanusiaan Yang Adil dan Beradab}

Menolong teman yang sedang kesusahan. Tidak membeda-bedakan dalam memilih teman. Berbagi makanan dengan teman lain jika sedang makan didepan teman lain. Mau mengajari teman yang belum paham dengan pelajaran tertentu. Memberikan tempat duduk kepada orang tua, ibu hamil, atau orang yang lebih membutuhkan saat ada di kendaraan umum. Tidak memaki-maki teman bersalah kepada kita. Meminta maaf atau memaafkan apabila melakukan kesalahan. Hormat dan patuh kepada guru, tidak membentakbentaknya. Hormat dan patuh kepada orang tua

\section{Persatuan Indonesia}

Mengikuti upacara bendera dengan tertib. Bergotong royong membersihkan lingkungan sekolah. Tidak berkelahi sesama teman maupun dengan orang lain. Memakai produk-produk dalam negeri. Menghormati setiap teman yang berbeda ras dan budayanya. Bangga menjadi warga negara Indonesia. Tidak sombong dan membanggabanggakan diri sendiri. Mengagumi keunggulan geografis dan kesuburan tanah wilayah Indonesia. 


\section{Kerakyatan Yang Dipimpin Oleh Hikmat Kebijaksanaan dalam Permusyawaratan Perwakilan.}

Membiasakan diri bermusyawarah dengan teman-teman dalam menyelesaikan masalah. Memberikan suara dalam pemilihan. Tidak boleh memaksakan kehendak kepada orang lain. Menerima kekalahan dengan ikhlas apabila kalah bersaing dengan teman lain. Dengan iktikad baik dan rasa tanggung jawab menerima dan melaksanakan hasil keputusan musyawarah. Berani mengkritik teman, ketua maupun guru yang bertindak semena-mena. Berani mengemukakan pendapat di depan umum. Melaksanakan segala aturan dan keputusan bersama dengan ikhlas dan bertanggung jawab.

\section{Keadilan Sosial Bagi Seluruh Rakyat Indonesia}

Berlaku adil kepada siapapun. Berbagi makanan kepada teman lain dengan sama rata. Seorang ketua memberikan tugas yang merata dan sesuai dengan kemampuan anggotanya. Seorang guru memberikan pujian kepada siswa yang rajin dan memberi nasihat kepada siswa yang malas. Tidak pilih-pilih dalam berteman. Tidak menggunakan hak milik untuk bertentangan dengan atau merugikan kepentingan umum. Suka bekerja keras

\section{Pentingnya Penerapan Nilai-Nilai Pancasila dalam Pendidikan Karakter}

Untuk membentuk generasi bangsa yang bermoral dan berkualitas tentunya memerlukan beberapa proses dalam penciptaannya. Salah satunya dengan membekali mereka dengan nilai-nilai luhur yang terkandung dalam Pancasila sebab Pancasila merupakan Dasar Negara dan Pandangan Hidup Bangsa dalam menjalankan kehidupannya. Mereka harus memahami, memaknai dan mengamalkan keseluruhan nilai-nilai yang terdapat dalam Pancasila karena nilai-nilai itu dapat menjadi fondasi dan benteng bagi mereka dari berbagai pengaruh yang dapat merusak moral mereka. Dengan penerapan nilai-nilai pancasila dalam pendidikan karakter maka sikap dan perilaku yang menyimpang akan menjadi lebih baik. Dan bentuk penyimpangan-penyimpangan tidak akan terjadi pada individu yang memiliki karakter dan jiwa yang nasionalis dan patriotis.

Berikut pentingnya penerapan nilai pancasila pada kehidupan: Menumbuhkan rasa cinta kepada Allah Yang Maha Esa dan Maha Kuasa. Menumbuhkan rasa cinta kepada anggota keluarga. Menumbuhkan rasa cinta dan hormat kepada orang tua dan orang yang lebih tua.. Mengembangkan sikap adil terhadap sesama. Menumbuhkan rasa dan sikap toleransi. Menumbuhkan rasa dan sikap gotong royong dan bekerja sama. Menumbuhkan sikap tenggang rasa. Menumbuhkan rasa cinta kepada setiap manusia dan tidak membeda-bedakan. Menumbuhkan rasa cinta bermusyawarah untuk mufakat. Menumbuhkan rasa cinta dan suka membantu orang lain yang susah. Meningkatkan rasa persaudaraan. Berorientasi ke masa depan dan menghargai perubahan dan kemajuan (the change and progres). Demokratis dan mewujudkan "civil society".

Mampu menjauhkan segala bentuk tindakan kekerasan dan pemaksaan. Memiliki kemandirian, kedaulatan, dan independensi. Menghargai kualitas, dan menjauhkan tindakan rasial dan diskriminasi. Menghargai karya, kreativitas dan produktivitas. Memiliki daya disiplin dan kepatuhan tinggi kepada aturan dan hukum formal. Memiliki paham nasionalisme dan patriotisme yang kokoh. Memiliki moralitas kemasyarakatan dan kebudayaan

\section{KESIMPULAN}

Pancasila memiliki nilai-nilai luhur yang dapat dijadikan pedoman hidup dalam 
berbangsa dan bernegara. Penanaman dan penerapan nilai-nilai Pancasila sangat penting dan diperlukan dalam membentuk kepribadian generasi bangsa yang berkarakter agar generasi dapat menghargai dan hidup dalam damai dan bermoral serta mampu bersaing dalam segala bidang.

Diharapkan agar semua lapisan masyarakat dapat menerapkan nilai-nilai yang terkandung dalam pancasila tidak hanya sebatas mengetaui saja namun melaksanakannya dalam kehidupan. Dan penerapan pendidikan karakter harus ditanamkan sejak dini agar kelak nilai pancasila akan melekat dalam karakter dan kepribadian tiap individu dalam bermasyarakat agar senantiasa tercipta bangsa Indonesia yang damai.

\section{DAFTAR PUSTAKA}

Alfaqi, M. Z. (2016). Melihat sejarah nasionalisme Indonesia untuk memupuk sikap kebangsaan generasi muda. Jurnal Civics: Media Kajian Kewarganegaraan, 13(2), 209-216. https://doi.org/10.21831/civics.v13i2.12745

Bahrudin, F. A. (2019). Implementasi Kompetensi Mata Kuliah Pendidikan Kewarganegaraan Di Perguruan Tinggi Dalam Menghadapi Tantangan Globalisasi. Pro Patria: Jurnal Pendidikan, Kewarganegaraan, Hukum, Sosial, Dan Politik, 2(2), 184-200. https://doi.org/10.47080/propatria.v2i2.593

Cahyo Pamungkas. (2015). Nasionalisme Masyarakat Di Perbatasan Laut: Studi Kasus Masyarakat Melayu-Karimun. Masyarakat Indonesia, 41(2), 147-162. http://ejournal.lipi.go.id/index.php/jmiipsk/article/view/253/119

Dedees, A. R. (2016). Melayu di Atas Tiga Bendera: Konstruksi Identitas Nasionalisme Masyarakat Perbatasan di Kepulauan Batam. Jurnal Ilmu Sosial Dan Ilmu Politik, 19(2), 141. https://doi.org/10.22146/jsp.10850

Dewantara, J. A., Hermawan, Y., Yunus, D., Prasetiyo, W. H., Efriani, Arifiyanti, F., \& Nurgiansah, T. H. (2021). Anti-Corruption Education as an Effort to Form Students With Character Humanist and Law-Compliant. Jurnal Civics: Media Kajian Kewarganegaraan, 18(1), 70-81.

Dewantara, J. A., \& Nurgiansah, T. H. (2021a). Building Tolerance Attitudes Of PPKN Students Through Multicultural Education Courses. Jurnal Etika Demokrasi, 6(1), 103-115.

Dewantara, J. A., \& Nurgiansah, T. H. (2021b). Efektivitas Pembelajaran Daring di Masa Covid19 Bagi Mahasiswa Universitas PGRI Yogyakarta. Jurnal Basicedu: Research \& Learning in Elementary Education, 5(1), 367-375.

Dewantara, J. A., Nurgiansah, T. H., \& Rachman, F. (2021). Mengatasi Pelanggaran Hak Asasi Manusia dengan Model Sekolah Ramah HAM (SR-HAM). Edukatif: Jurnal Ilmu Pendidikan, 3(2), 261-269.

Murdiono, M., Suyato, S., \& Arpannudin, I. (2020). Strategi Penguatan Nasionalisme Perbatasan Indonesia. Jurnal Pancasila Dan Kewarganegaraan, 5(2), 34-43. https://doi.org/10.24269/jpk.v5.n2.2020.pp34-43

Nurgiansah, T. H. (2020). Filsafat Pendidikan. In Banyumas: CV Pena Persada.

Nurgiansah, T. H. (2021a). Pendidikan Pancasila. In Solok: CV Mitra Cendekia Media.

Nurgiansah, T. H. (2021b). Pendidikan Pancasila Sebagai Upaya Membentuk Karakter Jujur. Jurnal Pendidikan Kewarganegaraan Undiksha, 9(1), 33-41.

Nurgiansah, T. H. (2021c). Petuah Pendidikan Kewarganegaraan Dalam Kontestasi Politik. AoEJ: Academy of Education Journal, 12(1), 39-47.

Nurgiansah, T. H. (2021d). The Role of Citizenship Education in Building Bantul Community Political Participation in The Pandemic Covid 19. Prosiding Seminar Nasional Pendidikan 
Dan Kewirausahaan, 4(1), 1-4.

Nurgiansah, T. H., \& Al Muchtar, S. (2018). Development of Student Awareness through Student Learning Model Jurisprudential in Citizenship Education. ATLANTIS PRESS, 251(Acec), 670-674. https://doi.org/10.2991/acec-18.2018.150

Nurgiansah, T. H., Dewantara, J. A., \& Rachman, F. (2020). The Implementation of Character Education in the Civics Education Syllabus at SMA Negeri 1 Sleman. Jurnal Etika Demokrasi, $5(2), 110-121$.

Retnasari, L., \& Hidayah, Y. (2019). Menumbuhkan Sikap Nasionalisme Warga Negara Muda di Era Globalisasi melalui Pendidikan Kewarganegaraan di Perguruan Tinggi (Studi pada Mahasiswa PGSD UAD). Jurnal Basicedu, 4(1), 79-88. https://doi.org/10.31004/basicedu.v4i1.303

Sutiyono, S. (2018). Reformulasi Pendidikan Pancasila Dan Kewarganegaraan Untuk Menguatkan Nasionalisme Warga Negara Muda Di Wilayah Perbatasan. Citizenship Jurnal Pancasila Dan Kewarganegaraan, 6(1), 1. https://doi.org/10.25273/citizenship.v6i1.1824

Wahyudi, W. (2017). Peran Kader Bela Negara Di Kawasan Perbatasan Dalam Dinamika Hubungan Lintas Batas Negara: Studi Tentang Peran Forum Bela Negara di Sebatik, Kabupaten Nunukan, Provinsi Kalimantan Utara. Jurnal Pertahanan \& Bela Negara, 7(3), 19-40. https://doi.org/10.33172/jpbh.v7i3.227

Yunita, Y., \& Suryadi, K. (2018). Rancang Bangun Pendidikan Bela Negara sebagai Wahana Pengembangan Sikap Nasionalisme Bagi Mahasiswa. MODELING: Jurnal Program Studi PGMI, 5(2), 225-233. 